\title{
Modelling growth and ingestion processes in herring Clupea harengus larvae
}

\author{
Øyvind Fiksen*, Arild Folkvord \\ Department of Fisheries and Marine Biology, University of Bergen, Høyteknologisenteret, N-5020 Bergen, Norway
}

\begin{abstract}
We present an individual-based model of growth processes (encounter rates, ingestion, assimilation and metabolism) in herring larvae. The model consolidates existing models on single processes and new experimental results on how temperature and food supply influence growth and survival (starvation) in this species. Environmental forces, such as wind (small-scale turbulence), light, turbidity, temperature, prey-density and -size structure, and intrinsic biological variables, such as larval size, ontogeny (prey-capture and visual capabilities) and starvation (point of no return), are all included in the model. A period just after yolk absorption is recognised when the larvae are particularly vulnerable to reduced food concentrations. Lack of food during this period may limit the development of the visual system and thereby the ability to detect and catch prey. Both experimental results and the simulations demonstrate the integrated effects of prey density, larval development and seasonal progression on growth processes. The growth difference between spring-and autumn-spawned larvae is suggested to be a result of seasonal variations in irradiance. Sensitivity analyses of parameters and submodels are performed.
\end{abstract}

KEY WORDS: Clupea harengus L. - Critical period. Feeding rate $\cdot$ Herring larvae $\cdot$ Match-mismatch . Individual-based model $\cdot$ Recruitment

\section{INTRODUCTION}

To understand the role of environmental variability on the growth of larval fish, it is essential to investigate the processes linking growth to the physical and biological properties of the natural habitat (Leggett \& Deblois 1994). Variation in recruitment from a given spawning stock biomass is related to the way these processes transpose onto the prospects of growth and survival of fish larvae. The integrated influence on these processes from several different environmental variables can only be adequately studied in numerical models (Houde 1997), while the reliability of the predictions from such models depends on our knowledge of the single processes.

Recruitment in many marine teleost fishes may be a function of prey availability during early life history (e.g. Cushing 1990, 1996). A variety of environmental factors influence the nature of the relation between fish larvae and their prey. In fact, the level of food lim-

•E-mail: oyvind.fiksen@ifm.uib.no itation in fish larvae could be regulated by variables other than prey density alone (Leggett \& Deblois 1994), and this may have masked the link between prey availability and larval survival. Among the most discussed external forces affecting larval growth rates are small-scale turbulence (Sundby \& Fossum 1990, MacKenzie et al. 1994, Muelbert et al. 1994, Sundby et al. 1994), light (Blaxter 1986, Miner \& Stein 1993, Suthers \& Sundby 1996, Fiksen et al. 1998), turbidity (Chesney 1989, Fortier et al. 1996) and temperature (Houde 1989, 1997). Each of these factors may cause recruitment variability irrespective of prey abundance; therefore it is important to develop a fundamental, quantitative understanding of how they are connected to larval growth and survival.

Herring larvae Clupea harengus L. are among the most thoroughly studied marine organisms, and several comprehensive models of a wide array of the basic biology have been developed for this species (Beyer 1980, Beyer \& Laurence 1981, Kiørboe et al. 1987 , Arrhenius \& Hansson 1993, Heath 1993, Kiørboe \& Saiz 1995). By merging several models and observa- 
tions, Fiksen et al. (1998) developed a detailed model of prey encounter rates in cod and herring larvae, accounting for development of visual ability, light conditions and small-scale turbulence. However, their model did not consider processes occurring after prey encounter (except the possibility that prey was lost due to turbulent motions, cf. McKenzie et al. 1994), such as probability of ingestion after encounter or growth as a function of ingestion. Here, we present a model including aspects from previous models by Beyer (1980), Kiørboe et al. (1987), Heath (1993), Kiørboe \& Saiz (1995) and Fiksen et al. (1998). All these models were developed to predict ingestion and growth rates in herring larvae. The model has several similarities with the model by Beyer \& Laurence (1981), but we have made the role of prey structure explicit and applied the most recent theories on how environmental factors such as turbulence and light modify food intake in fish larvae. In addition, we have included effects of temperature on growth rate as revealed in rearing experiments conducted on Norwegian spring-spawning herring (Folkvord et al. 1997a, in press).

\section{THE EXPERIMENTS}

Three experiments with Norwegian spring-spawning herring were carried out in consecutive years from 1995 to 1997 (Table 1). Eggs from 1 to 2 females and sperm from 3 to 6 males were stripped onto plastic sheets each year and incubated in the laboratory at 8.1 , 8.0 , and $6.0^{\circ} \mathrm{C}$ in Expts I to III, respectively. All the rearing experiments were carried out in $1 \mathrm{~m}^{2} 500 \mathrm{I}$ green fibreglass tanks. All temperature and food density treatments were replicated in 2 tanks (up to Day 16 and 18 in Expts I and II, and to the end of Expt III). Groups of 100 to 200 larvae were transferred to 51 buckets and kept without food at the respective temperatures each year as viability controls. Live natural zooplankton was used as prey in the rearing tanks, and consisted mainly of rotifers, nauplii, and calanoid copepods. Cultures of the algae Isochrysis spp. and Rhodomonas spp. were also added 3 to 7 times week $^{-1}$ in the tanks. The nominal prey densities and the tem- perature in the rearing tanks were checked and adjusted on a daily basis. The light intensities in the tanks varied according to the seasonal and daily cycles in Bergen, Norway $\left(60^{\circ} \mathrm{N}\right)$, using a computercontrolled light system, Lysstyr ${ }^{(B)}$ (Hansen 1990). Further details on the experiments are provided in Folkvord et al. (1997a, in press).

About 20 larvae were sampled weekly from each tank. Sampled larvae were staged according to Doyle (1977), measured alive for length to the nearest $0.1 \mathrm{~mm}$ under a dissecting microscope, and subsequently stored individually in vials with $96 \%$ ethanol (Expts I and II) or in Eppendorf vials in liquid $\mathrm{N}$ and thereafter in a $-80^{\circ} \mathrm{C}$ freezer (Expts II and III). Dry weights $( \pm 1 \mu \mathrm{g})$ were obtained on a microbalance after prior drying at $60^{\circ} \mathrm{C}$ for $24 \mathrm{~h}$ (Expts I and II) or $24 \mathrm{~h}$ in a freeze dryer (Expts II and III).

In total, 1660 larvae were sampled and measured live for length from the rearing tanks and viability controls during Expts I to III (Table 1). Overall survival, including sampling, ranged from 18 to $95 \%$ during the experiments.

\section{THE MODEL}

\section{Model individuals}

The model is initialised with 1 recently hatched larva, the dry body mass at hatching of which is the average of a population $(287 \pm 11.5 \mu \mathrm{g})$ of Norwegian spring-spawning herring larvae (as in Expt III). This larva metabolises yolk mass until their dry body mass reaches $233 \mu \mathrm{g}$, at which point it starts to feed. During this period, the model larva simply loses weight proportional to metabolism (Blaxter \& Hempel 1963). The respiration rate is set to $0.029 \mathrm{~g} \mathrm{~g}^{-1} \mathrm{~d}^{-1}$ at $8^{\circ} \mathrm{C}$ (Kiørboe et al. 1987), with a $Q_{10}$ of 2.6 (Almatar 1984). For yolk sac larvae, standard body length $(S L, \mathrm{~mm})$ is a decreasing function of dry body mass $(W, \mu \mathrm{g})[S L=(\ln W-$ $6.34) /-0.073 ; n=141, R^{2}=0.41$, i.e. larval length increases as yolk is metabolised.

Our representation of the state space of the feeding larva resembles the 'barrier model' described by Beyer

Table 1. Summary data of rearing experiments with Norwegian spring-spawning herring larvae. Hatching date, initial larval density, average rearing temperature, nominal prey density and total duration of experiment are indicated

\begin{tabular}{|lccccc|}
\hline Year-Expt & Hatching & $\begin{array}{c}\text { Larval density } \\
\left(\text { tank }^{-1}\right)\end{array}$ & $\begin{array}{c}\text { Temperature } \\
\left({ }^{\circ} \mathrm{C}\right)\end{array}$ & $\begin{array}{c}\text { Prey density } \\
\left(1^{-1}\right)\end{array}$ & $\begin{array}{c}\text { Duration } \\
(\mathrm{d})\end{array}$ \\
\hline $1995-$ I & Apr 16 & 400 & $4.0,12$ & 1000 & 37 \\
$1996-$ II & Apr 12 & 650 & 8.0 & 40,1200 & 46 \\
$1997-$ III & Apr 8 & 650 & $6.0,10.0$ & 40,1200 & 56 \\
\hline
\end{tabular}


\& Laurence (1981) (their Fig. 2). The realised growth rate can be positive or negative depending on environmental conditions, and the expected length of the larva is given by the observed length-weight relation $S L=$ ( $\ln W-2.9) / 0.21$ ( $\mathrm{n}=300, \mathrm{R}^{2}=0.97$, Expt III, $6^{\circ} \mathrm{C}$ ). If growth is positive, and body mass exceeds the expected value for the current length, then the length is updated to the expected value. Length is irreversible, while weight is dynamically coupled to growth rates. The larva dies from starvation if weight drops below $59 \%$ of the expected value (Werner \& Blaxter 1980).

\section{Foraging process}

Foraging is among the most difficult processes to implement in models of larval growth, because of the uncertainties in validating such models experimentally. It has been realised for some time that food densities must be elevated in the lab compared to natural environments to obtain similar growth rates (e.g. MacKenzie et al. 1990). Here, we have tried as far as possible to represent the foraging processes from first principles. This is appropriate for a species such as herring, for which a number of studies on several aspects of the growth and foraging processes have been presented. A number of events are required for a prey item to be ingested by a planktivore (e.g. Stephens \& Krebs 1986). First, the prey must be encountered and perceived as a suitable food so that an attack is profitable. While this decision is taken and an attack is prepared, the prey must not be lost from sight due to small-scale turbulence (MacKenzie et al. 1994). Further, the attack must be successful, and the larvae must overcome the escape response of the prey. The model treats each of these events sequentially, and all events must be successful for ingestion to take place. Parameters, units and references used in the model are listed in Table 2 .

\section{Prey encounter rate}

Encounter rate is of paramount importance in any foraging model. Fiksen et al. (1998) modelled herring larvae as cruising, visual predators (Rosenthal \& Hempel 1970, Munk \& Kiørboe 1985) in which prey encounter rate depends on a number of physical and biological variables. The whole process of encounter $e$ can be summarised as:

$$
e=q \pi r^{2} N V
$$

where $q$ is the fraction of the visual area that is effectively perceived while searching for food $\times$ the fraction of time the fish is actively searching for food, $r$ is visual range ( $q \pi r^{2}=$ the visual area scanned), $N$ is prey density and $V$ is the relative velocity of predator and prey (Table 2). The model by Fiksen et al. (1998) included a model for visual range in planktivorous fish, first presented by Aksnes \& Giske (1993) and later improved by Aksnes \& Utne (1997). These authors developed and calibrated the model of visual range as a function of background irradiance (light), water clarity (turbidity), the area of the image of the prey $A_{p}$, the contrast of the prey against the background and the sensitivity of the predator's eye. The sensitivity of the eye in herring (and cod) larvae increases strongly as the larvae develop (Fiksen et al. 1998), and this has implications for the predictions of food intake with respect to larval size.

In previous versions of the model by Aksnes \& Giske (1993), the apparent image of prey has been based on a spherical prey. Now, we allow for both spherical and elliptical prey shapes, and we include the possibility that prey is sighted from all possible angles. The expected image area $A_{p}$ of a spherical (eggs and early nauplii) or elliptical (copepodite) prey is a gradual function of prey length $l p$, prey width $d p$ (see Table 3 ) and angle $\theta$ between the long body axis of the larvae and the long body axis of the prey:

$$
A_{\mathrm{p}}=\frac{1}{\pi / 2} \int_{0}^{\pi / 2} 0.25 \pi d p \sqrt{A^{\prime}} \partial \theta=\frac{d p}{2} \int_{0}^{\pi / 2} \sqrt{A^{\prime}} \partial \theta
$$

where

$$
A^{\prime}=2\left\{\left(\frac{l p}{2}\right)^{2}+\left(\frac{d p}{2}\right)^{2}+\left[\left(\frac{l p}{2}\right)^{2}-\left(\frac{d p}{2}\right)^{2}\right] \cos 2 \theta\right\}
$$

For spherical prey $(l p=d p)$ the relative angle at encounter does not matter, while $A_{p}$ will decrease as $\theta$ approaches 0 (or $\pi$ ) and reach its maximal value at $\pi / 2$ (or $3 \pi / 2$ ) for ellipsoid prey. Otherwise, visual range is calculated as in previous versions of the model (Fiksen et al. 1998). The detailed implementation of visual range is justified by the sensitivity of this variable: any change in $r$ will be squared in $e$ (Eq. 1).

$V$ includes swimming speeds of predator and prey, and the effect of turbulence, as described by Rothschild \& Osborn (1988). We used visual range $r$ as the scale at which turbulence affects encounter rates (Evans 1989). Turbulence will stimulate encounter rates, but may reduce capture success (Mackenzie et al. 1994), so that the realised ingestion rate is

$$
I=e P_{\mathrm{sp}}
$$

where $P_{\mathrm{sp}}$ is the probability of successful pursuit of prey at a given level of turbulence, reaction distance and pursuit time. This factor will reduce capture success in highly energetic environments, where prey may pass the larvae too quickly to allow preparation of 
Table 2. Parameters, values, units and references for variables applied in the model

\begin{tabular}{|c|c|c|c|c|}
\hline Symbol & Description & Unit & $\begin{array}{l}\text { Value, } \\
\text { source }\end{array}$ & $\begin{array}{l}\text { Eq. or point at which } \\
\text { parameter appears }\end{array}$ \\
\hline$S L$ & Standard length of larvae & $\mathrm{mm}$ & & 10 , text \\
\hline$W$ & Larval dry body mass & $\mu g$ & & Text \\
\hline$e$ & Prey encounter rate & prey s ${ }^{-1}$ & & $1,4,8$ \\
\hline$q$ & $\begin{array}{l}\text { Fraction of visual area perceived } \times \text { fraction } \\
\text { of time spent searching for food }\end{array}$ & Dimensionless & $0.25^{a .1}$ & 1 \\
\hline$r$ & Visual range & $\mathrm{m}$ & b & 1 \\
\hline$N, N_{j}$ & Prey density & prey $\mathrm{m}^{-3}$ & & 1. Table 3 \\
\hline$V^{i}$ & Relative velocity between predator and prey & $\mathrm{m} \mathrm{s}^{-1}$ & b & 1 \\
\hline$A_{p}$ & Expected visual image of prey & $\mathrm{m}^{2}$ & & 2,3 , Table 3 \\
\hline$I p_{1}$ & Length of prey item $j$ & $\mathrm{~m}$ & & $2,3,10$, Table 3 \\
\hline$d p_{j}$ & Width of prey item $j$ & $\mathrm{~m}$ & & 2, 3, Table 3 \\
\hline$\theta$ & Prey angle at detection or during attack & Radians & $0-2 \pi$ & $2,3,5$ \\
\hline$I_{r} I_{j}$ & Ingestion rate & prey s ${ }^{-1}$ & & $4,8,9$ \\
\hline$P_{s p}$ & Probability of successful pursuit & Dimensionless & 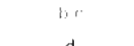 & 4,8 \\
\hline$P(a t t a c k \mid d)$ & Probability of attack if prey is detected & Dimensionless & d & 5,8 \\
\hline$P($ capturelattack) & Probability of prey capture given attack & Dimensionless & d & 7,8 \\
\hline$P($ engulf $\mid a t t a c k)$ & Probability of cleanly engulfing the prey & Dimensionless & d.e & 5,6 \\
\hline$\sigma$ & Strike precision parameter & $\mathrm{m}$ & $6 \times 10^{-5 e}$ & 6 \\
\hline$m$ & Mouth width $(m=0.0382 L-0.0147)$ & $\mathrm{m}$ & d & 6 \\
\hline$r p$ & Apparent length of prey at attack angle $\theta$ & $\mathrm{m}$ & $d$ & 6, text \\
\hline$c^{2}$ & Prey reaction distance in fractions of $L$ & Dimensionless & $0.5^{\mathrm{d}}$ & 7 \\
\hline$a$ & Attack distance in fractions of $L$ & Dimensionless & $0.07^{1}$ & 7 \\
\hline$E_{\mathrm{s}}, E_{\mathrm{b}}$ & Light at surface and at depth & 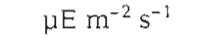 & & Fig. 5 \\
\hline hour & Hour of day $(1-24)$ & & & Fig. 5 \\
\hline day & Day of year $(1-365)$ & & & Fig. 5 \\
\hline$k$ & Light attenuation coefficient & $\mathrm{m}^{-1}$ & 0.13 & Fig. 5 \\
\hline$i_{\mathrm{T}}$ & Total food intake per day per larvae & $\mathrm{g} \mathrm{d}^{-1}$ & & 9 \\
\hline$i$ & Diel-specific ingestion rate & $\mathrm{g} \mathrm{g}^{-1} \mathrm{~d}^{-1}$ & & 11,14 \\
\hline$w_{j}$ & Dry mass of prey item $j$ & $\mu g d w$ & & Table 3 \\
\hline$h_{j}$ & Handling time of prey item $j$ & & & Table 3 \\
\hline$T$ & Temperature & ${ }^{\circ} \mathrm{C}$ & & $12,13,14$ \\
\hline$g$ & Diel-specific growth rate as a function of ingestion & $\mathrm{g} \mathrm{g}^{-1} \mathrm{~d}^{-1}$ & & 11 \\
\hline$g(T)$ & Diel-specific growth rate (temperature dependent) & $g g^{-1} d^{-1}$ & & 13 \\
\hline$g(i, T)$ & Diel-specific growth rate as a function of $i$ and $T$ & $g \mathrm{~g}^{-1} \mathrm{~d}^{-1}$ & & 14 \\
\hline$\gamma$ & Specific dynamic action & Dimensionless & g & 11 \\
\hline$\dot{\beta}$ & Fitted parameter (shape of $i$ - $g$ relationship) & Dimensionless & $7.6^{\mathrm{g}}$ & 11,14 \\
\hline$\alpha_{0}$ & Assimilation efficiency at very low ingestion rate & $\mathrm{g} \mathrm{g}^{-1} \mathrm{~d}^{-1}$ & g & 11 \\
\hline$K(T)$ & Temperature-dependent growth efficiency & $g \mathrm{~g}^{-1} \mathrm{~d}^{-1}$ & & 14 \\
\hline$r_{0}$ & Specific metabolic rate at starvation (and $8^{\circ} \mathrm{C}$ ) & $g g^{-1} d^{-1}$ & $0.029^{9}$ & 11 \\
\hline$r_{0}(T)$ & Temperature-dependent metabolic rate at starvation & $g g^{-1} d^{-1}$ & & 12,14 \\
\hline$Q_{10}$ & $Q_{10}$ relation of metabolic rate at starvation & Dimensionless & $2.6^{\mathrm{h}}$ & 12 \\
\hline$z$ & Depth & $\mathrm{m}$ & & Fig. 5 \\
\hline \multicolumn{5}{|c|}{ 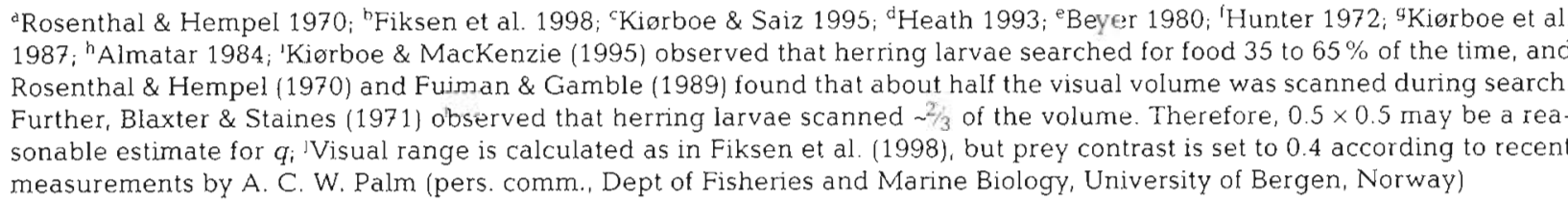 } \\
\hline
\end{tabular}

attack (see MacKenzie et al. 1994, Kiørboe \& Saiz, 1995, Fiksen et al. 1998 for details).

Fiksen et al. (1998) assumed that all prey encountered were ingested, except those that were lost due to turbulent motions during the time needed to prepare an attack (i.e. $P_{\mathrm{sp}}$ ). However, in order to make a realistic model of ingestion rates, it is essential to include effects of relative predator-prey size on capture success (Checkley 1982, Munk 1992, Heath 1993). We have adopted the approach from Beyer (1980) and Heath (1993) to find probability of attack given prey detection $P($ attack $\mid d)$ and probability of capture given attack $P$ (capturelattack). From geometrical arguments, Heath (1993) refined Beyer's formulation of the 
Table 3. Specification of prey parameters used in the simulations. Prey is assumed to be juvenile stages of Calanus finmarchicus

\begin{tabular}{|c|c|c|c|c|c|c|c|c|c|c|c|}
\hline & $\mathrm{Egg}$ & $\mathrm{NI}$ & NII & NIII & NIV & NV & NVI & $\mathrm{CI}$ & CII & CIII & CIV \\
\hline $1 p_{j}(\mathrm{~mm})$ & 0.1 & 0.1 & 0.2 & 0.3 & 0.4 & 0.5 & 0.6 & 0.8 & 1.0 & 1.5 & 2.0 \\
\hline$w_{j}(\mu g \mathrm{~d} w$ & 0.3 & 0.3 & 0.3 & 0.6 & 1.0 & 1.5 & 2.0 & 4.0 & 8.0 & 16.0 & 32.0 \\
\hline$N_{j}^{a}$ & 1.5 & 1.5 & 1.5 & 0.76 & 0.45 & 0.30 & 0.23 & 0.11 & 0.06 & 0.03 & 0.015 \\
\hline$h^{6}(s)$ & 1.34 & 1.34 & 1.39 & 1.45 & 1.52 & 1.60 & 1.70 & 1.95 & 2.33 & 4.53 & 14.9 \\
\hline$A_{p}\left(m^{2}\right)$ & $7.8 \times 10^{-3}$ & $7.8 \times 10^{-3}$ & $1.2 \times 10^{-2}$ & $1.7 \times 10^{-2}$ & $3.4 \times 10^{-2}$ & $4.1 \times 10^{-2}$ & $6.7 \times 10^{-2}$ & 0.19 & 0.30 & 0.68 & 1.21 \\
\hline
\end{tabular}

probability $P(e n g u l f \mid$ attack) that a prey of length $l p$ and width $d p$ is cleanly engulfed by a herring larvae with mouth-width $m$ :

$$
P(\text { attack } \mid d)=\int_{\theta=0}^{\theta=\pi / 2} P(\text { engulf } \mid \text { attack }) \partial \theta / \frac{\pi}{2}
$$

with

$$
P(\text { engulf lattack })=1-\exp \left[-\frac{1}{8} \sigma^{2}(m-r p)^{2}\right]
$$

when $m \geq r p$ and $P($ engulf $\mid$ attack $)=0$ if $m<r p$. Here, $\sigma$ is the strike precision parameter (Beyer 1980) and $r p$ is the apparent length of the prey item, depending on $l p$, $d p$ and attack angle $\theta: r p=\sqrt{A^{\prime}}$ (with $A^{\prime}$ as in Eq. 3). Thus, $P(a t t a c k \mid d)$ is a measure of the ease of capture for a given prey item by a predator with mouth width $m$, provided the strike angle (tilting of prey) is randomly distributed in the range 0 to $2 \pi$. In addition, we assume that the decision to attack is made according to ease of capture. Heath (1993) used P(attackld) $\times$ the volume of the prey as an index of prey preference, but we have not added any optimal foraging assumptions to our model.

We also included the second part of the attack sequence, the probability of capture given attack $P$ (capturelattack) as outlined by Heath (1993). This is dependent on the escape abilities of prey, and was derived as a function of the prey (lp) and predator $(L)$ length (see Fig. 2 in Heath 1993):

$$
P(\text { capturelattack })=\left\{\begin{aligned}
{[1-(c \cdot l p) /(a \cdot L)]^{2} } & \text { for } l p / L \leq a / c \\
& \text { for } l p / L>a / C
\end{aligned}\right.
$$

where $c$ is prey reaction distance in fractions of prey length and $a$ is attack distance in fractions of larval length. The parameter $a$ is assumed constant $(0.07$; Hunter 1972), while $c$ is likely to be specific for each prey species. Heath (1993) found that $c=1.2$ gave a nice fit $\left(\mathrm{R}^{2}=0.99\right)$ to data from Blaxter \& Staines (1971), while $c=0.5$ gave better agreement with observations from Munk (1992). This parameter is uncertain, but it is clear that a more elongate prey item has better escape abilities (e.g. Hays et al. 1997).

Now, the ingestion rate can be reformulated to include the events after encounter:

$$
I=e P_{\mathrm{sp}} P(\text { attack } \mid d) P(\text { capturelattack) }
$$

Ingestion rate can also be affected by time spent on prey handling, i.e. time required to pursue, capture and consume prey (included all the failures). Since herring larvae will utilise a wide range of prey items as they grow, the total food (dry mass) intake per day $i_{\Upsilon}$ is best described by a multiple prey model, like the Holling's disc equation (Holling 1966, Stephens \& Krebs 1986):

$$
i_{\mathrm{T}}=\sum_{24 \mathrm{~h}}\left(\frac{\sum_{j=1}^{n} 3600 \cdot I, w_{j}}{1+\sum_{j=1}^{n} 3600 \cdot I, h_{j}}\right)
$$

where $I_{j}$ is ingestion rate (Eq. 8), $w_{j}$ is dry mass and $h_{j}$ is handling time of prey type $j$ (11 possible items, see Table 3). Handling time (time required to attack, capture and swallow the prey) is likely to be a function of the relative size of predator and prey, but no data on this is available for herring larvae (only pursuit time, Munk \& Kiørboe 1985). Therefore, we have applied the empirical relation from bluegill sunfish Lepomis macrochirus feeding on Daphnia magna derived by Walton et al. (1992):

$$
\ln h_{j}=0.264 .10^{7.0151 / p / S L}
$$

Light and ingestion rate will change with season, during the day and with depth, so diel-specific ingestion is calculated by summing up $i_{\mathrm{T}}$ for each hour. Since a number of the physical parameters of the model vary with depth, the vertical profile of the water column and the vertical history of each larval individual must be specified. A simple model also used by Rosland \& Giske (1994) was used to represent diel and seasonal variations in illumination at the surface. 

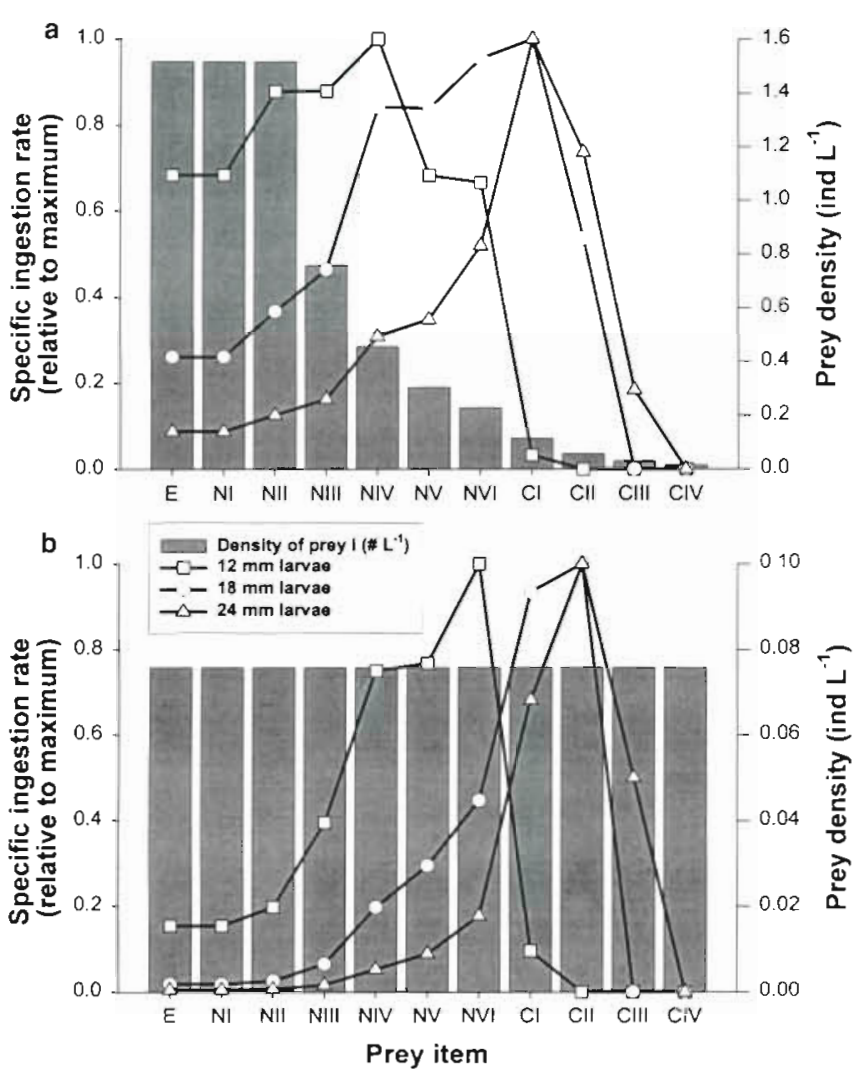

Fig. 1. Model simulation of prey abundance (shaded bars) and specific ingestion rate (relative to maximum ingestion of each larval length) when 12, 18 and $24 \mathrm{~mm}$ herring larvae are offered a diet consisting of 1 single prey stage (Calanus finmarchicus) during 1 day (day of year $=90$, latitude $=60^{\circ} \mathrm{N}$, depth $=10 \mathrm{~m}$ ). (a) Biomass concentration is the same for each

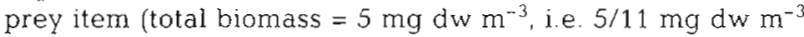
in each stage). (b) Equal number of prey in each stage, i.e. biomass increases sharply to the largest prey (to the right). The number of prey items in each stage is set so that the total biomass still equals $5 \mathrm{mg} \mathrm{dw} \mathrm{m}^{-3}$ The simulations are done assuming no wind

We have defined prey to be eggs, nauplii and early copepodites of Calanus finmarchicus, one of the most important prey of herring larvae. Each prey type $j$ has a specified length $l p_{j}$ width $d p_{j}$ and dry mass $w_{j}$ (Table 3 ). As our default version, we have assumed that the prey concentration in terms of biomass $\mathrm{m}^{-3}$ is the same for all prey types, consequently prey density (ind. $\mathrm{m}^{-3}$ ) decrease for the larger categories (Table 3, Fig. 1, shaded bars). Note that the baseline food concentration of $5 \mathrm{mg}$ dry mass of prey $\mathrm{m}^{-3}$ corresponds to $5 \mathrm{NIV}^{-1}$ if this is the sole prey item. This prey density is reasonable for springspawned herring larvae in the Norwegian Coastal Current (Fossum \& Moksness 1993, Fossum 1996). However, the assumption of equal biomass across stages implies that almost $40 \%$ of the prey biomass is copepodites, so this resource availability may be considered to be in the lower range (see 'Discussion').

\section{Assimilation and growth}

Kiørboe et al. (1987) derived a model of daily specific growth rate $g$ in herring larvae as a function of specific ingestion rate $i\left[=i_{T}\right.$ (from Eq. 9) $/ W$ (larval dry mass)]:

$$
g=\frac{(1-\gamma) \alpha_{0}}{\beta}\left(1-e^{-\beta i}\right)-r_{0}
$$

where $\alpha_{0}$ is the assimilation efficiency at low (zero) ingestion rate, $\gamma$ is specific dynamic action, $\beta$ is a constant and $r_{0}$ is specific metabolic rate at starvation. Kiørboe et al. (1987) were able to parameterise this model by grouping $(1-\gamma) \alpha_{0} / \beta$ into a parameter $K$, and then fitting the equation $g=K\left(1-\mathrm{e}^{-B^{\prime}}\right)-r_{0}$ to their data by adjusting $K_{1} \beta$ and $r_{0}$. These values were derived for $8^{\circ} \mathrm{C}$ by Kiørboe et al. (1987). By use of growth rates from Expts I to III, we have included the dependency of temperature on growth rates in the model. It is known that respiration rates $\left(r_{0}\right)$ increase with temperature (de Silva \& Tytler 1971, Almatar 1984). Since experiments in our lab and elsewhere (Laurence 1978, Houde 1989) have revealed significantly higher growth rates at increased temperatures when food is supplied in excess, it is apparent that $K$ must be more positively affected by temperature than respiration.

Almatar (1984) found the $Q_{10}$ of the respiration rate during starvation $\left(r_{0}\right)$ to be 2.6. Therefore,

$$
r_{0}(T)=0.029 Q_{10}^{(T-8) / 10}
$$

where 0.029 is respiration at $8^{\circ} \mathrm{C}$ (Kiørboe et al. 1987), $T$ is temperature and $Q_{10}=2.6$. From Expts I to III the following temperature-dependent relation to mean growth rate for larvae smaller than $22 \mathrm{~mm}$ (and stage > 1c, Doyle 1977) fed ad libitum was found:

$$
g(T)=-0.024+0.012 T \quad n=5, R^{2}=0.97
$$

Since the maximum temperature-dependent growth rate from Eq. 13 (Expts I to III) is the net growth after metabolic processes, we introduce $K(T)=g(T)+T_{0}(T)$. Finally, with the assumption that $\beta$ (from Kiørboe et al. 1987) does not change with temperature, we can add ingestion to the growth expression and obtain a model of growth that is both food and temperature dependent:

$$
g(i, T)=K(T)\left(1-\mathrm{e}^{-\beta i}\right)-r_{0}(T)
$$

\section{RESULTS}

\section{Prey abundance and size structure}

The effects of relative and absolute predator and prey size are inherent in several of the processes rep- 
resented in the model. To illustrate how this influences the model predictions, we calculated specific ingestion rates of larvae of various sizes that were offered 1 prey type at a time (Fig. 1). We present 2 scenarios, one with equal biomass (the standard used in all other simulations) and one with equal numbers of each prey item. In both situations, food availability restrains growth. In the case of equal biomass, the smallest larvae $(12 \mathrm{~mm}$, length at first feeding) will have fairly similar ingestion rates from a diet of eggs and all naupliar stages, but they will have severe problems to capture any copepodites. Intermediate larvae $(18 \mathrm{~mm})$ have a broad range of profitable prey sizes; it can feed quite efficiently on both nauplii and copepodite stages (except CIII and CIV). The largest larvae (24 mm) has the narrowest range of profitable prey, with a conspicuous peak at CI. Though the larger larvae can consume a larger number of small prey, this does not compensate for their larger body mass. When prey concentration is held fixed, the differences in profitability increase, and larger prey will give higher specific ingestion rates for all larval sizes. It is important to realise that if prey is eggs or e.g. NVI the same concentration will result in a factor of 10 difference in growth.

Individual trajectories of weight and body length are compared with data from the rearing experiments (Fig. 2). The larvae hatch and have internal food supply (yolk) during the first $-9 \mathrm{~d}$ at $6^{\circ} \mathrm{C}$. Their weight drops, but length increase during this time. A close connection between the development of high food ration larvae in the tanks and the modelled growth at high food concentrations is expected, as the data were used to generate temperature-dependent growth (Eq. 13). Also, it is not possible to make a direct quantitative comparison between the low food ration experiments and the model, since larvae reared in the laboratory for some reason require artificially high densities to survive compared to natural or mesocosm conditions (e.g. Øiestad 1985, Folkvord et al. 1997b). However, both the model and the experimental data suggest that larvae are most sensitive to low food concentrations in the period after the yolk sac is absorbed and exogenous feeding is initialised. Pedersen et al. (1990) found similar results in experiments on larval herring from the Clyde Sea. If the larvae can grow beyond 13 to 14 mm length, they will be limited by food only at the lowest food concentrations. In the model, this result is connected to the development of the search and capture abilities of the larvae. In particular, the relationship between larval length and visual range (see Fiksen et al. 1998) will cause a positive feedback reaction, where successful ingestion events just after yolk absorption will increase larval length, visual range and encounter rate sequentially. Since visual range initially is expo- nentially related to length (Fiksen et al. 1998) and squared in the expression for encounter rate (Eq. 1), the benefit of high food levels during early larval phase is obvious. If ingestion rates are initially low, and the larvae ingest just enough food to balance metabolism, the larvae will not improve their visual and swimming abilities, and will be trapped in a vulnerable condition.

At low food rations in both the experiments and in the model, the larvae do not grow in the first $\sim 20 \mathrm{~d}$ after absorption of the yolk sac (Fig. 2). Increased length and weight coincides with the increase in light that took place during the experimental (and modelled) time period. Longer days and increased irradiance enhance prey encounter rates, and thus reduce the food abundance required for growth.
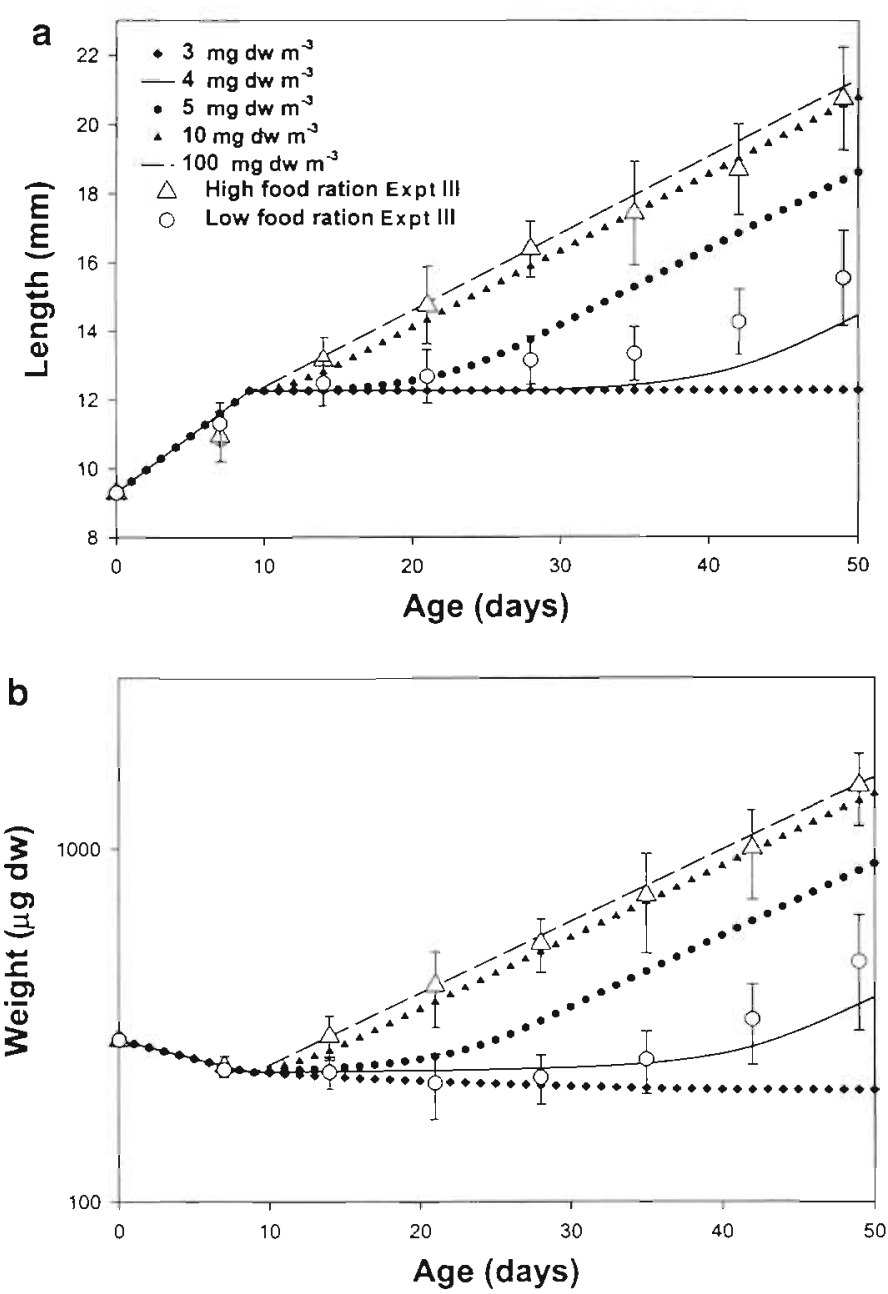

Fig. 2. Growth by (a) length and (b) weight of herring larvae at $6^{\circ} \mathrm{C}$, for a range of food densities ( 3 to $100 \mathrm{mg} \mathrm{dw} \mathrm{m}^{-3}$ ). The data from Expt III are included in the plots. The simulations are made at $10 \mathrm{~m}$ depth, starting at day of the year $=105$,

which correspond in time with the experiments (Table 1) 


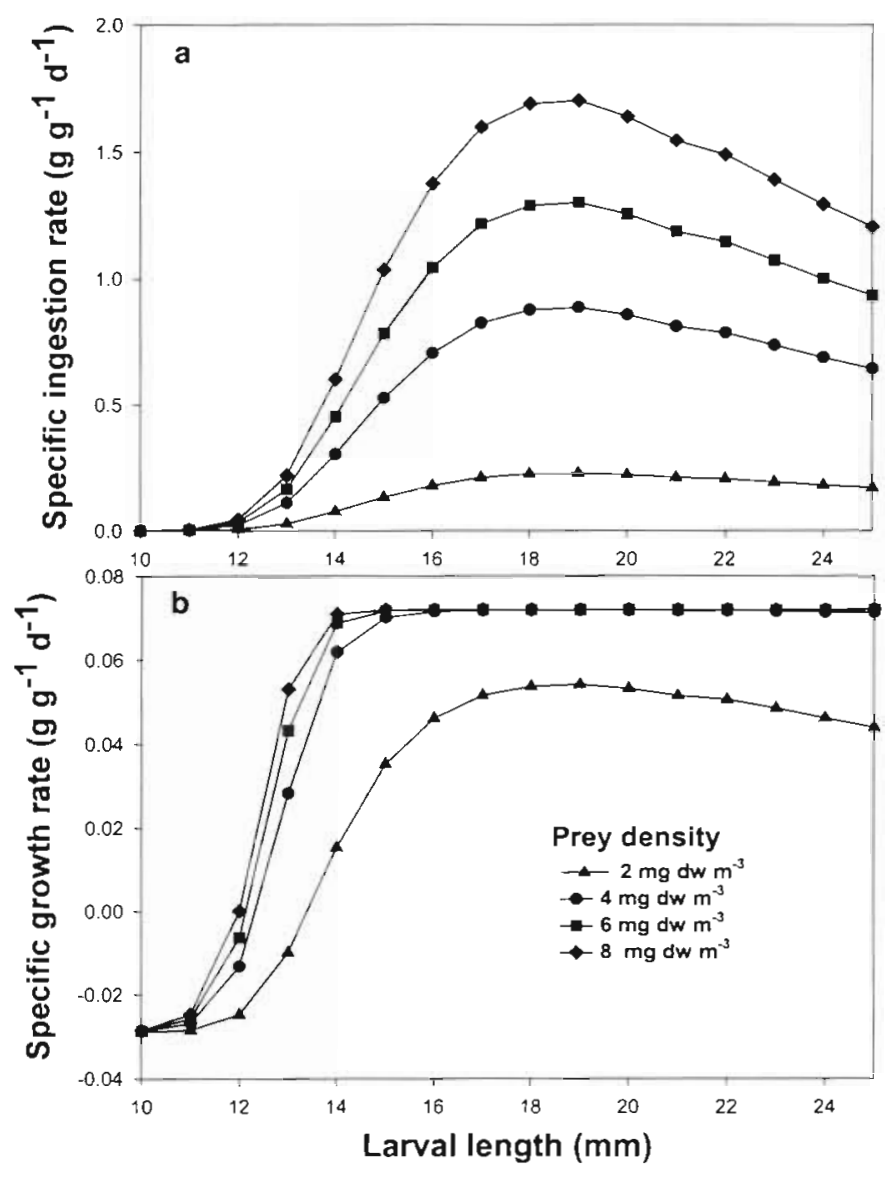

Fig. 3. (a) Ingestion and (b) growth rate as a function of larval length and prey density. Prey structure was kept constant in all simulations (total biomass similar for all prey categories in Table 3, while numbers vary). Simulations are made for day of the year $=90$

The sensitivity to food availability at first exogenous feeding is detailed in Fig. 3. At first feeding (about $12.2 \mathrm{~mm}$ ) the specific ingestion rate will be just high enough to ensure positive growth rates at 4 to $5 \mathrm{mg} \mathrm{dw} \mathrm{m}^{-3}$. Beyond 13 to $14 \mathrm{~mm}$ the larvae will be able to manage on $2 \mathrm{mg} \mathrm{dw}^{-3}$, but with this food ration they will never get through the critical period, or rather, the critical size window between 12 and $13 \mathrm{~mm}$. Growth soon becomes food satiated for the larger larvae (except for food concentrations lower than about $3 \mathrm{mg} \mathrm{dw} \mathrm{m}^{-3}$ ). Specific ingestion rates level off and eventually decline, as visual development is completed and visual range reach maximum levels, while body mass continues to increase. The shape of the specific ingestion rate with size in well-fed larvae is highly correlated to the development of the visual system (Fiksen et al. 1998).

\section{Temperature}

The combined temperature and food dependence (Eq. 14) on growth rate is presented in Fig. 4. The effect of temperature is profound, with an increase of growth rates of $0.012 \mathrm{~g} \mathrm{~g}^{-1} \mathrm{~d}^{-1}{ }^{\circ} \mathrm{C}^{-1}$ (Eq. 13) at high ingestion rates. Imposed in Fig. 4 is also the expression from Kiørboe et al. (1987), and at $8^{\circ} \mathrm{C}$ the growth of satiated Norwegian spring-spawners was about $0.02 \mathrm{~g}$ $\mathrm{g}^{-1} \mathrm{~d}^{-1}$ lower than larvae from the Clyde Sea and Limfjorden area.

\section{Seasonal effects on growth}

The seasonal variation in irradiance has been proposed as a possible explanation for the differences in growth between spring - and autumn-spawned herring larvae (Gamble et al. 1985). The model is formulated such that both spring-and autumn-spawned larvae can be simulated simply by altering the date (day of year) at hatching. Illumination and thus ingestion rates will change seasonally, diurnally (Fig. 5) and with depth; larvae hatched in mid April (Day 105) will grow faster than larvae hatched in early October (Day 270) under otherwise similar conditions (Fig. 6). Autumnspawned larvae will be more sensitive to low food abundance, due to shorter (and decreasing) day length, lower sun height and reduced irradiance. In nature, the actual light regime will be heavily influenced by light extinction properties of the water column and the migratory behaviour of the larvae. At high prey densities, however, growth is governed by temperature and no difference is apparent. Along the Norwegian coast, temperatures are higher in autumn (October) than during spring (April). Some simulations

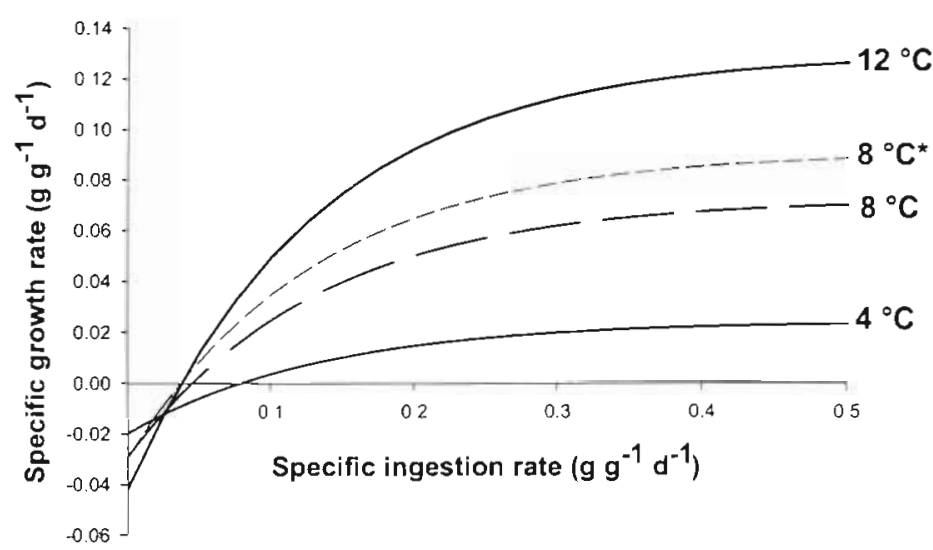

Fig. 4. Growth of larvae plotted as function of specific ingestion and temperature (cf. Eq. 14, no effects of size). The dashed line $\left(8^{\circ} \mathrm{C}\right.$, with an asterisk) is the equation derived by Kiørboe et al. (1987) 


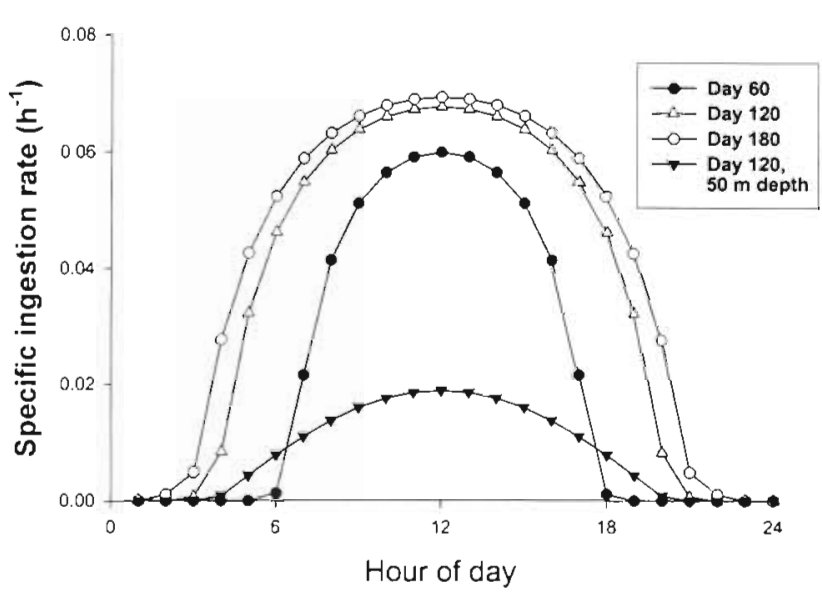

Fig. 5. Diel variation in ingestion rates at different dates. Light

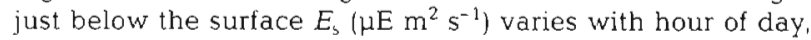
day of the year [light at midday $=50+500 \sin (\pi d a y / 365)$ ], and latitude (cf. Rosland \& Giske 1994). Local background irradiance $E_{b}$ is attenuated with depth depending on the attenuation (turbidity) coefficient $\left(=0.13 \mathrm{~m}^{-1}\right) \mathrm{k}: E_{\mathrm{b}}=E_{\mathrm{s}}$ (hour)exp(-kz) (see Table 2). Simulations are made with a 16 $\mathrm{mm}$ larvae at $30(50) \mathrm{m}$ depth, $6^{\circ} \mathrm{C}$ and with prey density $=$ $5 \mathrm{mg} \mathrm{dw} \mathrm{m} \mathrm{m}^{-3}$

with realistic temperatures $\left(9\right.$ to $11^{\circ} \mathrm{C}$ at $10 \mathrm{~m}$ depth from early October to late November and 5 to $7^{\circ} \mathrm{C}$ in April to May) gave substantially higher growth rates in autumn for all prey densities (not shown). Higher temperature will also make the larvae able to survive in lower prey densities, since growth increases faster than respiration with temperature (Eqs, 12 to 14 ).

\section{Effect of wind and depth distribution}

Depth distribution is important to growth success in the model, even if the temperature is assumed not to vary vertically (Table 4). Just a few metres of difference in vertical position can make a pronounced distinction in growth trajectories. If a larva descends slowly (from 5 to $25 \mathrm{~m}$ ), it will grow bigger within $40 \mathrm{~d}$ than if it ascends (from 25 to $5 \mathrm{~m}$ ). Again, this illustrates

Table 4 . Body mass after $40 \mathrm{~d}$ for 5 different vertical trajectories through the water column (hatched at Day 90, $5 \mathrm{mg}$ prey $\mathrm{m}^{-3}$ and $6^{\circ} \mathrm{C}$ throughout the water column)

\begin{tabular}{|lc|}
\hline $\begin{array}{l}\text { Vertical behaviour } \\
\text { Descent from } 5 \text { to } 25 \mathrm{~m}\end{array}$ & $\begin{array}{c}\text { Body mass after } 40 \mathrm{~d} \\
(\mu \mathrm{g})\end{array}$ \\
\hline Fixed at $10 \mathrm{~m}$ & 394.1 \\
Fixed at $15 \mathrm{~m}$ & 467.8 \\
Fixed at $20 \mathrm{~m}$ & 371.6 \\
Ascent from 25 to $5 \mathrm{~m}$ & 251.2 \\
& 359.9 \\
\hline
\end{tabular}

the importance of prey encounter rate in the time just after yolk absorption: ascending individuals will be at about $20 \mathrm{~m}$ depth at this vulnerable stage, while descending larvae will be at $10 \mathrm{~m}$ depth and in a better light environment. Naturally, the sensitivity of depth distribution is related to turbidity (particles, algal biomass, etc.). We have applied an attenuation coefficient of $0.13 \mathrm{~m}^{-1}$ (Fig. 5 legend) in all simulations, corresponding roughly to the coastal water where these larvae develop.

Light and wind-generated turbulence produce marked vertical profiles in growth rates (Fig. 7). Larvae at different developmental stages will have different vertical profiles in the same environment, mainly because of their visual abilities (Fig. 7). The growth rate can be food limited in deeper waters and food satiated near surface for any given food concentration. Wind-generated small-scale turbulence may double ingestion rates in herring larvae (Fiksen et al. 1998), but may improve growth rates by at most $20 \%$ provided that food concentration is low (Fig. $7 \mathrm{c}$ ). Turbulence will not affect growth in larger herring because they become encounter satiated at higher prey densities. The model predicts that turbulence has negative impact on growth rates in first feeding herring larvae (see Fiksen et al. 1998), and will only benefit larger larvae at low food concentrations (due to satiation). This is caused by their relatively larger size (high swimming speed) and visual range, and that the pursuit success will be reduced with increasing turbulence for planktivores with a small visual volume (MacKenzie et al. 1994, Dower et al. 1997).

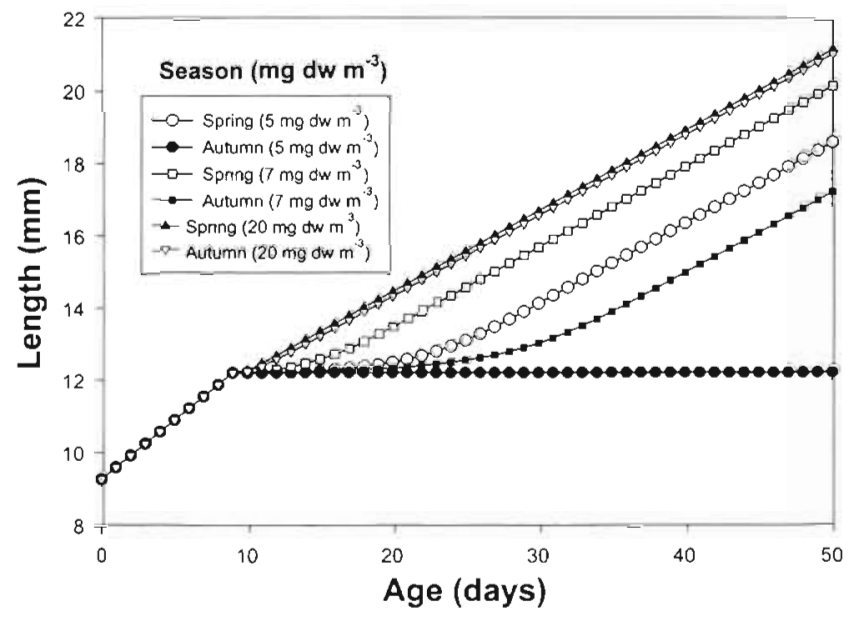

Fig. 6. Difference between spring- and autumn-spawned individuals $\left(10 \mathrm{~m}\right.$ depth, $\left.6^{\circ} \mathrm{C}\right)$ at 3 food concentrations. Springspawned herring hatch at Day 105 (mid April) and autumnspawned at Day 270 (early October). The difference between spring and autumn is caused by difference in irradiance only

(Fig. 5) 

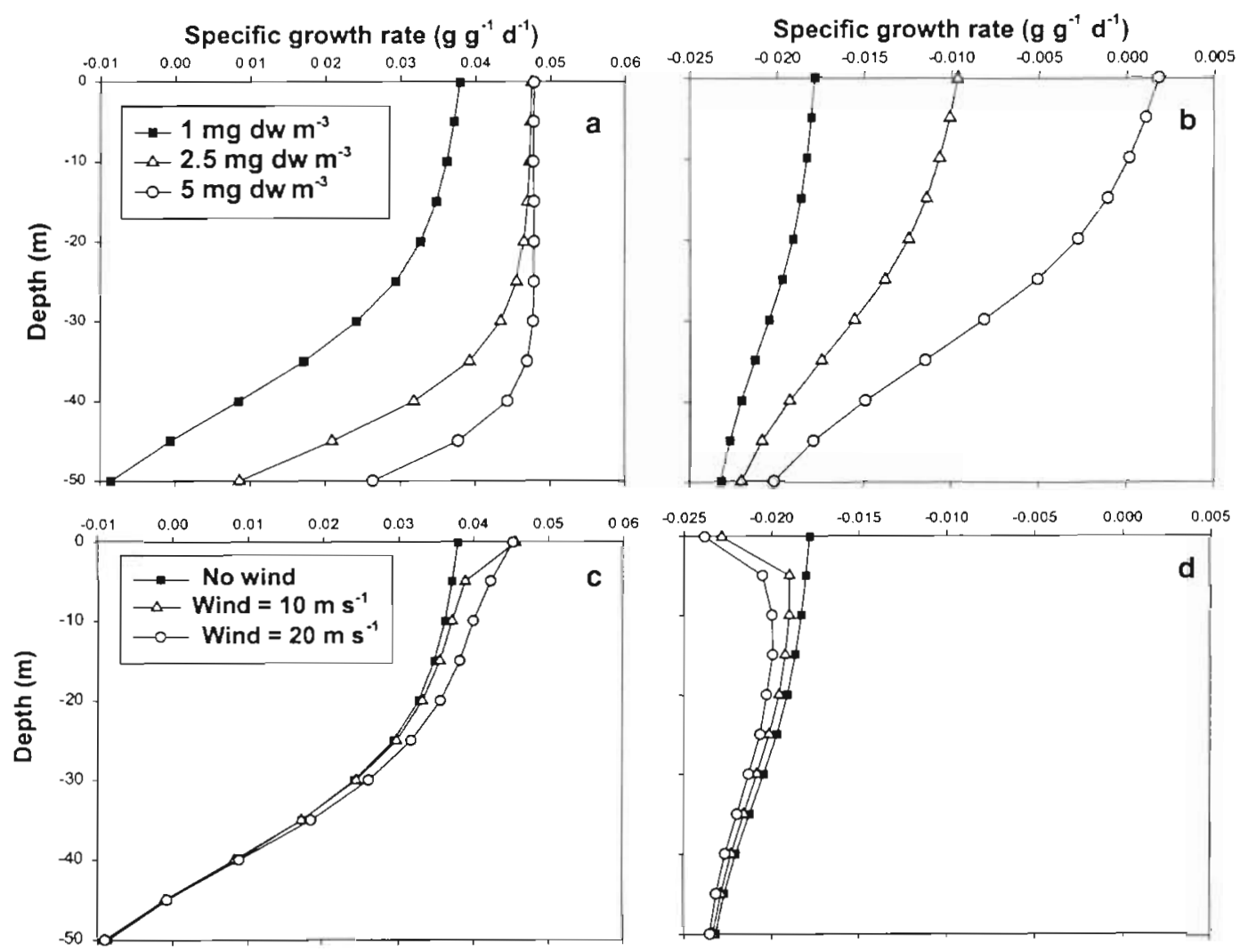

Fig. 7 Vertical profiles of growth rates for different food and wind conditions. All points are calculated for 1 larva in a fixed depth position during 1 diel cycle ( $24 \mathrm{~h}$ ). Light attenuation was as in Fig. 5 for Day 90. (a,b) Vertical profiles for (a) $16 \mathrm{~mm}$ and (b) first feeding (12.2 mm) larvae under 3 food densities (no wind $6^{\circ} \mathrm{C}$ in all depths). (c,d) The effect of wind velocities near surface on growth rate of a $16 \mathrm{~mm}$ larva and a first feeding larva $(12.2 \mathrm{~mm})$ at low food density $\left(1 \mathrm{mg} \mathrm{dw} \mathrm{m}^{-3}\right)$. The vertical profile of turbulence (energy dissipation rate) as a function of wind at the surface was assumed as in MacKenzie \& Leggett (1993) and

Fiksen et al. (1998). Notice that all other simulations (including $a$ and $b$ above) are done with no wind at surface

\section{Match-mismatch}

A simple representation of different 'match-mismatch' situations is presented in Fig. 8. If April (Days 90 to 120 ) is a period when food (nauplii and copepods) flourish (increase from 3 to $10 \mathrm{mg} \mathrm{dw} \mathrm{m}^{-3}$ ), and hatching takes place before, during or after the nauplii outburst, then hatching time will be important to growth rates. Obviously, it is better to have the first $15 \mathrm{~d}$ in the nauplii bloom and the next $35 \mathrm{~d}$ outside, than to have the first $15 \mathrm{~d}$ outside and the next $30 \mathrm{~d}$ in the high food situation. There is no notable difference in the growth trajectories of a larva with perfect 'match' (hatched at Day 90) compared to the larva hatched 15 d later. The important point is to have abundant food when exogenous feeding is initialised. The influence of increasing day-length as spring advances is also evident and quite strong as hatching on Day 120 (complete 'mismatch') will give similar body mass after $50 \mathrm{~d}$ as hatching at Day 75, although the latter experience $30 \mathrm{~d}$ of food in excess (Fig. 8).

\section{Sensitivity analysis}

We performed some simple analyses of the sensitivity of growth to modifications of the model structure (Table 5) and to some of the model parameters (Table 5, Fig. 9). The first change was to simplify the prey structure, and as long as both nauplii and copepodites are present, the results remain the same. The important aspect is the available biomass in the nauplii size range, particularly in the $0.4 \times 0.15 \mathrm{~mm}$ category (Tables $3 \& 5$ ). The grouping of prey into coarser size groups will save CPU time and may facilitate simulations where the model is forced with real data or integrated into circulation models. The model is not at all sensitive to handling time, which is fortunate, since this regression (Eq. 10) was taken from other species.

On the other hand, the model is highly sensitive to the attack and capture process. When all prey are encountered at an angle of $90^{\circ}$ so that the visual image of the prey is always at its maximum (approximately $l p_{j}$ $\times d p_{j} \times 0.7$ ), then body mass after 50 d increase by $43 \%$. 


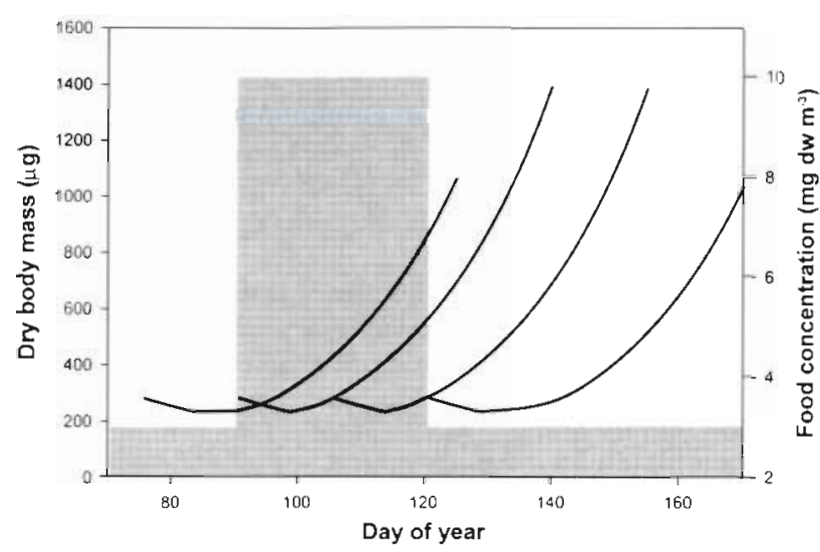

Fig. 8. Growth curves at various hatching times relative to an intermediate increase in food availability (shaded area). Temperature is $6^{\circ} \mathrm{C}$, and the larvae stay at $10 \mathrm{~m}$ depth

If all prey encountered are successfully ingested, the larvae will increase its growth rate substantially or survive on far lower prey concentrations. Thus, the model is also sensitive to the correspondent parameters $a, c$ and $\sigma$ (Fig. 9). Not surprisingly, the model is also sensitive to swimming speed (Table 5) and to the combined search efficiency and activity level parameter $q$ (Fig. 9), at least at this level of food abundance. The biology behind these parameters is connected, as increased search velocity or activity level is likely to reduce search (or capture) efficiency (Kiflawi \& Genin 1997), at least beyond some lower levels. More accurate estimates of the relations between herring larvae and their food resources would be possible if these parameters were known with greater certainty.

Maybe more surprising is the results of adding wind at the surface (Table 5). Obviously, due to its negative effect on capture success $P_{\mathrm{sp}}$ (Eq. 4), turbulence will reduce growth in herring larvae, particularly in the smaller stages with short reactive distance. These issues were treated in depth by Fiksen et al. (1998). Naturally, if the anticipated drop in pursuit success due to turbulent motions is left out $\left(P_{\mathrm{sp}}=1\right)$, then turbulence will be beneficial to growth (Table 5).

Larvae that are supplied with larger amounts of yolk at hatching will be able to fulfil more of their development on endogenous food supplies. Therefore, it will be able to bypass the critical size window and initialise first feeding with a functional brain and visual apparatus, and, consequently, a longer reactive distance. This can improve growth considerably (Table 5), at least if matter and energy is allocated in fixed proportions between the nervous system and somatic growth (as assumed in the model).

\section{DISCUSSION}

\section{The model}

Our model has no 'free' parameters that can be tuned to obtain 'reasonable' results, all parameters have clear biological or physical meaning, and their values have been measured experimentally. With 3

Table 5. Sensitivity analysis of changes in some of the model processes. All simulations are done for single (and identical) individuals residing at $10 \mathrm{~m}$ depth, starting at Day 90 , with a food concentration of $5 \mathrm{mg} \mathrm{dw}^{-3}$ and no wind (unless stated)

\begin{tabular}{|c|c|c|c|}
\hline $\mathrm{Eq}$. & Modification & Body mass after $50 \mathrm{~d}(\mu \mathrm{g})$ & $\%$ change from baseline \\
\hline & Baseline & 744.95 & 0 \\
\hline & Prey: NIV and CII & 797.28 & 7.0 \\
\hline & Prey: NIV & 1401.13 & 88.1 \\
\hline & Prey: $\mathrm{Cl}$ (or larger) & Starved & - \\
\hline & Prey: NI & 1084.7 & 45.6 \\
\hline 9,10 & Handling time $=0$ & 747.2 & 0.3 \\
\hline 7,8 & $P($ capturelattack $)=1$ & 1283.7 & 72.3 \\
\hline $5,6,8$ & $P(\operatorname{attack} \mid d)=1$ & 1538.9 & 106.6 \\
\hline $5-8$ & $P($ attack $\mid d) \times P($ capturelattack $)=1$ & 1592.3 & 113.7 \\
\hline 2,3 & Encounter angle $=90^{\circ}$ & 1065.8 & 43.1 \\
\hline 1 & Swim speed $\times 1.1$ & 915.8 & 22.9 \\
\hline 1 & Swim speed $\times 0.9$ & 481.4 & -35.4 \\
\hline 1,4 & Wind at surface $=10 \mathrm{~m} \mathrm{~s}^{-1}$ & 428.6 & -42.5 \\
\hline 1,4 & Wind at surface $=20 \mathrm{~m} \mathrm{~s}^{-1}$ & Starved & - \\
\hline 1,4 & $P_{s p}=1$, wind $=10 \mathrm{~m} \mathrm{~s}^{-1}$ & 856.0 & 14.9 \\
\hline \multirow[t]{5}{*}{1,4} & $P_{\mathrm{sp}}=1$, wind $=20 \mathrm{~m} \mathrm{~s}^{-1}$ & 1057.0 & 41.9 \\
\hline & Size at first feeding $=12.1 \mathrm{~mm}$ & 661.8 & -11.2 \\
\hline & Size at first feeding $=12.3 \mathrm{~mm}$ & 1406.2 & 88.8 \\
\hline & Size at first feeding $=12.5 \mathrm{~mm}$ & 1644.5 & 120.8 \\
\hline & Size at first feeding $=12.7 \mathrm{~mm}$ & 1807.8 & 142.7 \\
\hline
\end{tabular}




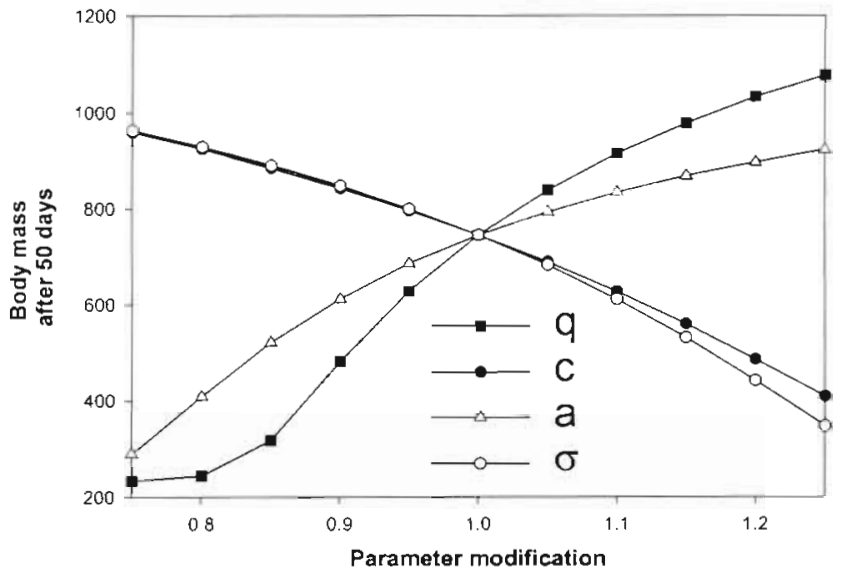

Fig. 9. The effect on body mass $(\mu \mathrm{g})$ of a series of runs with increasing parameter values $(q=$ activity $\times$ visual efficiency, $c$ = prey reaction distance, $a=$ attack distance, $\sigma=$ strike precision parameter). The crossing point represents the baseline version

exceptions, we only used models and parameters that have been developed or measured for herring larvae. The first exception is the size dependency in prey handling time ( $E q .10$ ), but the model is not at all sensitive to this assumption (Table 5). The second exception is the multi-species regression giving size-dependent swimming speed $\left(=10^{1.07 \log l-1.11}, l\right.$ in $\mathrm{mm}$, speed in $\mathrm{cm} \mathrm{s}^{-1}$ ) from Miller et al. (1988), also used by Fiksen et al. (1998). Arrhenius (1998) developed a relation for swimming speed in herring larvae $\left[=5.76 W^{0386} \exp (0.0238 T), W=0.0053 L^{3.02}, W\right.$ is wet mass $(\mathrm{g}), L$ is length $(\mathrm{mm}), T$ is temperature $\left.\left({ }^{\circ} \mathrm{C}\right)\right]$ that is practically indistinguishable from the one in Miller et al. (1988) in the 10 to $30 \mathrm{~mm}$ range. Even so, swimming speed is highly flexible, and should be treated in terms of behavioural ecology and optimality theory (Dill 1983). The third exception is the time needed to prepare an attack under turbulent conditions (see MacKenzie et al. 1994, Kiørboe \& Saiz 1995, Fiksen et al. 1998), also a length-dependent function $[=1.33 \exp$ $(-0.0035 l), l$ in $\mathrm{mm}$, from Dower et al. 1997]. Munk \& Kiørboe (1985) estimated the time required for a $12 \mathrm{~mm}$ herring larvae to be $\sim 1 \mathrm{~s}$, and Hunter (1972) found values of 1.3 to $1.8 \mathrm{~s}$ for similar sized anchovies, while the equation from Dower et al. (1997) will give values $\sim 1.3 \mathrm{~s}$ for all relevant sizes

The emphasis on mechanism, environment and species-specific parameterisation is the main difference between our model and many other individual-based models on fish larvae trophodynamics. The models combining individual-based models and general circulation models (e.g. Hinckley et al. 1996, Werner et al. 1996, overview in Heath \& Gallego 1997) must be parsimonious to be computationally feasible. Therefore, processes like ingestion are often simplified to a degree where the environmental influence is very low. For instance, Hinckley et al. (1996) modelled consumption as an empirical function of body weight and temperature and Werner et al. (1996) ignored light (except day/night switch) and the influence of turbulence on prey capture success. Including these processes could potentially change some of the predictions from these studies, particularly due to the lack of vertical light profiles and corresponding effects on prey consumption (Fiksen et al. 1998). In conclusion, we believe that the refinement of the biological formulations (growth, mortality, environment) are fundamental to increased understanding of recruitment processes (Heath \& Gallego 1997).

Though we have confined our model to contain formulations and values derived for herring larvae, there may also be significant differences between herring stocks. For instance, the relative size of the yolk sac at hatching may vary by a factor of 7 from one stock to another (Blaxter \& Hempel 1963, Kiørboe et al. 1985). In addition, variables like length-weight relations, size of yolk sac or size at first feeding are likely to vary between individuals and stocks. We believe that the difference in maximum growth rate at $8^{\circ} \mathrm{C}$ between this study and Kiørboe et al. (1987) (about $0.02 \mathrm{~d}^{-1}$, Fig. 4) can be attributed to such causes.

Our data from Norwegian spring-spawning herring suggested that first feeding took place at a fixed weight $(223 \mu \mathrm{g})$. This leaves no room for individual variation, and hatching at a larger size will be unprofitable since it then has to spend more time in the yolk stage. However, as demonstrated in the sensitivity analyses, more yolk at hatching may allow for enhanced ontogenetic development without exogenous nutrition, and can reduce the duration of the larval stage substantially (Table 5). Although the data in the experiments did not show a significant variation in size at first feeding, this may be important in nature, where mothers differ in size and condition (maternal effects, Blaxter \& Hunter 1982).

Not many models of fish foraging have modelled reactive distance explicitly as a function of light or body length. Rose \& Cowan (1993) and Letcher et al. (1996) used a length-dependent expression from bluegill sunfish Lepomis macrochirus derived by Breck \& Gitter (1983). Chesney (1993) developed a model for bass larvae with light, turbidity and prey density represented directly from empirical functions. These authors (and others) made feeding depend on a lower light threshold, below which feeding did not occur, so that feeding was restricted to a prescribed fraction of the day. With the model derived by Aksnes \& Giske (1993), Aksnes \& Utne (1997) and Fiksen et al. (1998), the effects of improved visual acuity (e.g. Fuiman \& 
Higgs 1997), turbidity, ambient light, prey size and prey contrast is brought together in a natural framework. Rosland \& Giske (1994, 1997) took a similar approach to calculate prey encounter in Müllers pearlside Maurolicus muelleri. Giske et al. (1994) explored several ecological properties of an earlier version of the model for reactive distance also applied here. We believe that these factors (light environment, visual abilities) are essential in understanding how visual hunters like planktivores are affected by fluctuations in their food resources. When making inferences about e.g. habitat selection or optimal foraging in fish larvae as a function of e.g. prey distribution and ontogeny (e.g. Fortier \& Harris 1989), the depth (light) should be considered to be more important to habitat quality than local prey abundance (Aksnes \& Giske 1993). This also applies to risk of predation; a deep habitat may be safer although the density of planktivore predators is higher. In the present model, it is assumed that the development of the visual system is directly connected to growth; if growth slows down, then the development of brain and visual apparatus is also delayed. This need not be quite so, the larvae may allocate scarce resources to develop its vital senses. However, starved individuals have clearly reduced brain development and visual abilities (Packard \& Wainwright 1974). Therefore, the critical size window (12 to $13 \mathrm{~mm}$ ) in the modelled larvae does not relate directly to starvation, but to cessation of development and growth in a vulnerable state where energy and matter for fulfilling development are difficult to obtain.

This is the first model to include all aspects (encounter rate and pursuit success) of small-scale turbulence and to relate it to growth, not just prey encounter or ingestion. Obviously, as anticipated by Dower et al. (1997), turbulence reduced feeding and growth in the smallest larvae (Fig. 7). According to the model, larger larvae will increase their ingestion rate in intermediate energetic environments (Fiksen et al. 1998), but the effect on growth is negligible because they are less likely to be food limited as they increase in size.

\section{Prey density and food limitation}

In a field survey on Norwegian spring-spawning herring, Fossum \& Moksness (1993) found that, during spring 1990, the prey abundance (copepod eggs and nauplii) increased from 1 to $4 \mathrm{I}^{-1}$ during hatching and about 1 mo after $50 \%$ hatching. This was a situation of low larval survival (mismatch), and the survivors seemed to be those hatching later in the year. Fossum (1996) reviewed the data on survival of and food availability for herring larvae from a series of surveys in spring during 1985 to 1993 on the Norwegian shelf.
The highest survival of larvae corresponded with the highest prey densities $\left(14 \mathrm{l}^{-1}\right)$ and a good temporal overlap (match) in 1993 (for various reasons, cod decimated this year-class in the Barents Sea). The most frequently observed prey densities during these surveys were between $\sim 7$ and 0.5 copepod eggs and nauplii $\mathrm{l}^{-1}$, i.e. at densities where our model would predict food-limited growth. Folkvord et al. (1997b) observed starvation and low RNA/DNA ratios in herring larvae (from the Buchan area, Scotland) in mesocosms at prey densities below $0.5 \mathrm{I}^{-1}$. They also observed severe limitation on growth as prey density decreased from 8 to less than 1 prey $1^{-1}$, and an increase in growth as prey densities increased from 0.1 to $>31^{-1}$. During a cruise to the southern spawning grounds of Norwegian spring-spawning herring, Johannessen et al. (1995) found prey (nauplii < $0.6 \mathrm{~mm}$ ) densities of 2.8 to $7.5 \mathrm{l}^{-1}$ at times of hatching. In the same area, Bjorke (1978) estimated an average prey availability of $6.3 \mathrm{I}^{-1}$, mainly Calanus eggs. The overall impression from all these studies is that herring larvae frequently experience food limitation in nature. Kiorboe et al. (1988) reached similar conclusions from a study in the Buchan area, and they further suggested that patches of herring larvae could affect their prey densities. In an experimental study, Kiorboe \& Munk (1986) found larvae of Baltic and Downs herring to become satiated at nauplii (from Acartia tonsa) densities of $5 \mathrm{mg} \mathrm{dw} \mathrm{m}^{-3}$. Our model suggests that prey density should impose a continuous impact on growth rates during first feeding over a quite wide range, from 0 to about $10 \mathrm{mg} \mathrm{dw} \mathrm{m}^{-3}$ (Fig. 2). Food limitation is most severe below 4 to $5 \mathrm{mg} \mathrm{dw} \mathrm{m}^{-3}$ (Fig. 3), very similar to the results by Kiørboe \& Munk (1986). This corresponds roughly to 0 to $5 \mathrm{NIV}$ or 0 to 15 Calanus eggs $\mathrm{l}^{-1}$, and indicates that the model produces sensible results for growth as a function of prey density. This is encouraging, bearing in mind that the model does not have any tuned parameters and that the model is based primarily on explanatory (as opposed to descriptive) formulations (Loehle 1983).

Compared with the model by Beyer \& Laurence (1981), herring larvae can sustain growth on far lower prey densities in our model. While their basic version used 100 nauplii (each $0.8 \mu \mathrm{g} \mathrm{dw}$ ) $\mathrm{l}^{-1}$ or $80 \mathrm{mg} \mathrm{dw} \mathrm{m}^{-3}$,

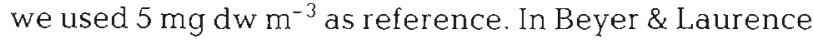
(1981), herring larvae needed at least 25 nauplii $\mathrm{l}^{-1}$ to survive, which is 5 to 6 times as much as in our model. From the literature cited above, it is clear that our model is more concordant with available field data, and that Beyer \& Laurence (1981) relied on prey densities required in the laboratory. However, Beyer \& Laurence (1981) found that smaller larvae were more susceptible to low food concentrations, which agrees well with our predictions. Also, optimal prey size were similar be- 
tween the 2 models. We found CII ( $0.5 \mathrm{~mm}$ wide) to be the most profitable prey to larvae larger than $18 \mathrm{~mm}$, and NIV to NVI $(0.15$ to $0.2 \mathrm{~mm})$ for first feeding larvae (Fig. 1). Beyer (1980) found optimal prey width to be $0.24 \mathrm{~mm}$ for first feeding larvae and $0.55 \mathrm{~mm}$ for $20 \mathrm{~mm}$ larvae. This conformity is expected, since the models have similar formulations of capture success

The model predicted that growth, under similar prey densities, should be higher in autumn due to higher temperatures at this time of the year. This prediction holds although the reduced irradiance and daylength are considered and suggests that prey availability is, eventually, limiting growth in herring larvae spawned during autumn along the Norwegian coast or in the North Sea area. However, if temperature and prey density are similar, growth will be highest in spring as long as food is limiting.

\section{The importance of behaviour}

The effect on growth from prey abundance disappears gradually as a function of both increasing prey density and larval size (Fig, 3). In addition, if fish larvae behave like optimal foragers (e.g. Dill 1983), increased food availability may reduce mortality risk through several mechanisms (Munk \& Kiørboe 1985, McNamara \& Houston 1987, Fossum 1996). Abundant food would make it profitable to spend more time in deeper waters, where fish predators cannot see them, or to reduce swimming speeds, so that encounters with entangling (tactile) predators are minimised. It is not obvious whether growth should be increased or mortality reduced when such behaviourally mediated options are present (Fiksen \& Giske 1995). The optimal solutions to this trade-off will depend on the relative costs and benefits of e.g. increasing size versus survival. The present version of the model has not considered behaviour, but several of the model parameters like swimming speed and activity (Munk \& Kiørboe 1985) and vertical distribution (e.g. Blaxter \& Hunter 1982) are known to be responsive to environmental or internal conditions. It is clearly erroneous to apply single values or to impose ad hoc rules to such important and flexible traits. An altemative may be to optimise these parameters such that fitness, or some proxy for fitness, like survival to metamorphosis, is maximised (e.g. Fiksen \& Giske 1995).

\section{Future directions of research-applications of the model}

Here, we did not attempt to employ the model in a natural environment, i.e. using measured input values of irradiance, temperature, prey size, abundance, etc. to force the model. Several field programs have provided such input data, with corresponding measures of growth of herring larvae (Johannessen 1986. Heath et al. 1988, Kiørboe et al. 1988, Fossum 1996, Gallego et al. 1996). The most controlled validation of the model may be obtained from simulating mesocosm experiments, such as the one by Folkvord et al. (1997b). However, such work is not yet available for Norwegian spring-spawning herring, and the model will need some modification (size at hatching, visual ontogeny, etc.) before being pertinent to other herring stocks. The ability of the model to replicate patterns of growth will indicate how suited it is as a tool for predicting and understanding recruitment variability in herring

We have not considered predation risk here, yet there exist a number of experimental and theoretical studies on the susceptibility and vulnerability of herring larvae to fish and gelatinous predators (Bailey \& Batty 1983, Bailey \& Houde 1989, Fuiman 1989, Fuiman \& Gamble 1989, Cowan \& Houde 1992, Cowan et al. 1996, 1997). Clearly, a model of encounter and probability of ingestion between a larva and its planktivore (e.g. Rosland \& Giske 1994, 1997) or tactile (Bailey \& Batty 1983, Eiane et al. 1997) predator should be developed for herring.

The fluctuations of fish stocks may result from variable growth and survival during the larval stages (Anderson 1988, Leggett \& Deblois 1994, Cushing 1996). Several hypotheses regarding the annual variability of year class strength have been put forward, the most famous being 'the critical period' concept of Hjort (1914) and the 'match-mismatch' hypothesis of Cushing $(1990,1996)$. Both of these consider food intake, growth and the impact of growth on survival. Our model is not an attempt to distinguish these hypotheses, rather it suggests a way to unify them. The development of individual-based models provides a method of specifying physiological and developmental features of larvae, and therefore the recognition of critical or sensitive periods in the fish life cycle. By combining quantitative representations of the critical period (or the critical size window) concept with environmental fluctuations in environment, resources and predators (match-mismatch), we may be able to unify these 2 concepts within a single framework. By including resource dynamics, we may also determine levels of secondary production or spawning stock biomass where density dependence becomes important (Cushing 1983, Bollens 1988, Bollens et al. 1992, Cushing \& Horwood 1994).

Acknowledgements. Thanks to Jani Sassi for useful suggestions on the algorithm, to Dag L. Aksnes, Jarl Giske and Svein Sundby for their comments on the manuscript, and to Hans Hoie, Arne Johannessen and Frank Midtøy for help during 
the experiments. The remarks from several referees improved the quality of the manuscript. $\varnothing . F$. was supported by a grant from the research council of Norway (NRC) (114646/120) and the experimental studies were supported by EU FAIR-CT 961371 and NRC grant 108103/122.

\section{LITERATURE CITED}

Aksnes DL, Giske J (1993) A theoretical model of aquatic visual feeding. Ecol Model 67:233-250

Aksnes DL, Utne ACW (1997) A revised model of the visual range in fish. Sarsia 82:137-147

Almatar SM (1984) Effects of acute changes in temperature and salinity on the oxygen uptake of larvae of herring (Clupea harengus) and plaice (Pleuronectes platessa). Mar Biol 80:117-124

Anderson JT (1988) A review of size dependent survival during pre-recruit stages of fishes in relation to recruitment. J Northw Atl Fish Sci 8:55-66

Arrhenius $F(1998)$ Variable length of daily feeding period in bioenergetics modelling: a test with 0-group Baltic herring. J Fish Biol 52:855-860

Arrhenius F, Hansson S (1993) Food consumption of larval, young and adult herring and sprat in the Baltic Sea. Mar Ecol Prog Ser 96:125-137

Bailey KM, Batty RS (1983) A laboratory study of predation by Aurelia aurita on larval herring (Clupea harengus): experimental observations compared with model predictions. Mar Biol 72:295-301

Bailey KM, Houde ED (1989) Predation on eggs and larvae of marine fishes and the recruitment problem. Adv Mar Biol 25:1-83

Beyer JE (1980) Feeding success of clupeoid fish larvae and stochastic thinking. Dana 1:65-91

Beyer JE, Laurence GC (1981) Aspects of stochasticity in modelling growth and survival of clupeoid fish larvae. Rapp PV Réun Cons Int Explor Mer 178:17-23

Bjorke $H$ (1978) Food and feeding of young herring larvae of Norwegian spring spawners. Fiskeri dir Skr Ser Havunders 16:405-421

Blaxter JHS (1986) Development of sense organs and behaviour of teleost larvae with special reference to feeding and predator avoidance. Trans A.m Fish Soc 115:98-114

Blaxter JHS, Hempel G (1963) The influence of egg size on herring larvae (Clupea harengus L.). J Cons Perm Int Explor Mer 28:211-240

Blaxter JHS, Hunter JR (1982) The biology of the clupeoid fishes. Adv Mar Biol 20:1-223

Blaxter JHS, Staines M (1971) Food searching potential in marine fish larvae. In: Crisp DJ (ed) Larval biology. 4th European Marine Biology Symposium Bangor, North Wales, 14-20 September 1969. Cambridge University Press, London, p 467-485

Bollens SM (1988) A model of predatory impact of larval marine fish on the population dynamics of their zooplankton prey. J Plankton Res 10:887-906

Bollens SM, Frost BW, Schwaninger HR, Davis CS, Way KJ, Landsteiner MC (1992) Seasonal plankton cycles in a temperate fjord and comments on the match-mismatch hypothesis. J Plankton Res 14:1279-1305

Breck JE. Gitter MJ (1983) Effect of fish size on the reactive distance of bluegill (Lepomis macrochirus) sunfish. Can J Fish Aquat Sci 40:162-167

Checkley DM (1982) Selective feeding by Atlantic herring (Cluped harengus) larvae on zooplankton in natural assemblages. Mar Ecol Prog Ser 9:245-253
Chesney EJ Jr (1989) Estimating the food requirements of striped bass larvae Morone saxatilis: effects of light, turbidity and turbulence. Mar Ecol Prog Ser 53:191-200

Chesney EJ (1993) A model of survival and growth of striped bass larvae Morone saxatilis in the Potomac River, 1987. Mar Ecol Prog Ser 92:15-25

Cowan JH Jr, Houde ED (1992) Size-dependent predation on marine fish larvae by ctenophores, scyphomedusae, and planktivorous fish. Fish Oceanogr 1:113-126

Cowan JH Jr, Houde ED, Rose KA (1996) Size-dependent vulnerability of marine fish larvae to predation: an individualbased numerical experiment. ICES J Mar Sci 53:23-37

Cowan JH Jr, Rose KA, Houde ED (1997) Size-based foraging success and vulnerability to predation: selection of survivors in individual-based models of larval fish populations. In: Chambers RC, Trippel EA (eds) Early life history and recruitment in fish populations. Fish and Fisheries Series 21, Chapman \& Hall, London, p 357-386

Cushing DH (1983) Are fish larvae too dilute to affect the density of their food organisms? J Plankton Res 5:847-854

Cushing DH (1990) Plankton production and year-class strength in fish populations: an update of the match/mismatch hypothesis. Adv Mar Biol 26:249-293

Cushing DH (1996) Towards a science of recruitment in fish populations. In: Kinne $O$ (ed) Excellence in ecology, Book 7. Ecology Institute, Oldendorf/Luhe

Cushing DH, Horwood JW (1994) The growth and death of fish larvae. J Plankton Res 16:291-300

de Silva CD. Tytler P (1973) The influence of reduced environmental oxygen on the metabolism and survival of herring and plaice larvae. Neth J Sea Res 7:345-362

Dill LM (1983) Adaptive flexibility in the foraging behaviour of fishes. Can J Fish Aquat Sci 40:398-408

Dower JF, Miller TJ, Leggett WC (1997) The role of microscale turbulence in the feeding ecology of larval fish. Adv Mar Biol 31:169-220

Doyle MJ (1977) A morphological staging system for the larval development of the herring. Clupea harengus L. J Mar Biol Assoc UK 57:859-867

Eiane K, Aksnes DL, Giske J (1997) The significance of optical properties in competition among visual and tactile predators: a theoretical study. Ecol Model 98:123-136

Evans GT (1989) The encounter speed of moving predator and prey. J Plankton Res 11:415-417

Fiksen $\varnothing$, Giske J (1995) Vertical distribution and population dynamics of copepods by dynamic optimization. ICES J Mar Sci 52:483-503

Fiksen $\varnothing$, Utne ACW, Aksnes DL, Eiane K, Helvik JV, Sundby $S$ (1998) Modelling the influence of light, turbulence and development on foraging in larval cod and herring. Fish Oceanogr 7:354-363

Folkvord A, Johannessen A, Moksness E, Fossum P (1997a) Temperature dependent otolith growth in herring (Clupea harengus) larvae. J Fish Biol 51:404 (abstract)

Folkvord A, Rukan K, Johannessen A, Moksness E (1997b) Early life history of herring larvae in contrasting feeding environments determined by otolith microstructure analysis. J Fish Biol 51:250-263

Folkvord A, Blom G, Johannessen A, Moksness E (in press) Growth dependent age estimation in herring (Clupea harengus L.) larvae. Fish Res

Fortier L, Harris RP (1989) Optimal foraging and densitydependent competition in marine fish larvae. Mar Ecol Prog Ser 51:19-33

Fortier L, Gilbert M, Ponton D, Ingram RG, Robineau B, Legendre L (1996) Impact of freshwater on a subarctic coastal ecosystem under seasonal ice (southeastern Hud- 
son Bay, Canada). III. Feeding success of marine fish larvae. J Mar Sys 7:251-265

Fossum P (1996) A study of first-feeding herring (Clupea harengus L.) larvae during the period 1985-1993. ICES J Mar Sci 53:51-59

Fossum P. Moksness E (1993) A study of spring- and autumnspawned herring (Clupea harengus L.) larvae in the Norwegian Coastal Current during spring 1990. Fish Oceanogr 2:73-81

Fuiman LA (1989) Vulnerability of Atlantic herring larvae to predation by yearling herring. Mar Ecol Prog Ser 51 291-299

Fuiman LA, Gamble JC (1989) Influence of experimental manipulations on predation of herring larvae by juvenile herring in large enclosures. Rapp PV Réun Cons Int Exp Mer 191:359-365

Fuiman LA, Higgs DM (1997) Ontogeny, growth and the recruitment process. In: Chambers RC, Trippel EA (eds) Early life history and recruitment in fish populations. Fish and Fisheries Series 21, Chapman \& Hall, London, p 225-249

Gallego A, Heath MR, McKenzie E, Cargill LH (1996) Environmentally induced short-term variability in the growth rates of herring. Mar Ecol Prog Ser 137:11-23

Gamble JC, MacLachlan PM, Seaton DD (1985) Comparative growth and development of autumn and spring spawned Atlantic herring larvae reared in large enclosed ecosystems. Mar Ecol Prog Ser 26:19-33

Giske J, Aksnes DL, Fiksen $\oslash$ (1994) Visual predators, environmental variables and zooplankton mortality risk. Vie Milieu 44:1-9

Hansen EH (1990) Bruk av kunstig lys og lysmanipulering for styrt produksjon av laksefisk. PhD thesis, NTH, University of Trondheim

Hays GC, Warner AJ, Tranter P (1997) Why do the two most abundant copepods in the North Atlantic differ so markedly in their diel vertical migration behaviour? J Sea Res 38:85-92

Heath MR (1993) The role of escape reactions in determining the size distribution of prey captured by herring larvae. Environ Biol Fish 38:331-344

Heath MR, Gallego A (1997) From the biology of the individual to the dynamics of the population: bridging the gap in fish early life studies. J Fish Biol 51(Suppl A):1-29

Heath MR, Henderson EW, Baird DL (1988) Vertical distribution of herring larvae in relation to physical mixing and illumination. Mar Ecol Prog Ser 47:211-228

Hinckley S, Hermann AJ, Megrey BA (1996) Development of a spatially explicit, individual-based model of marine fish early life history. Mar Ecol Prog Ser 139:47-68

Hjort J (1914) Fluctuations in the great fisheries of Northern Europe viewed in the light of biological research. Rapp PV Réun Cons Int Exp Mer 20:1-228

Holling CS (1966) The functional response of invertebrate predators to prey density. Mem Entomol Soc Can 48:1-86

Houde ED (1989) Comparative growth, mortality and energetics of marine fish larvae: temperature and implied latitudinal effects. Fish Bull US 87:471-495

Houde ED (1997) Patterns and consequences of selective processes in teleost early life histories. In: Chambers RC, Trippel EA (eds) Early life history and recruitment in fish populations. Fish and Fisheries Series 21, Chapman \& Hall, London, p 171-196

Hunter JR (1972) Swimming and feeding behaviour of larval anchovy, Engraulis mordax. Fish Bull US 70:821-838

Johannessen A (1986) Recruitment studies of herring (Clupea harengus L.) in Lindaaspollene, western Norway, 1-3. Fiskeridir Skr Ser Havunders 18:139-240
Johannessen A, Blom G, Folkvord A, Svendsen H (1995) The effect of local wind on the distribution of Norwegian spring spawning herring (Clupea harengus L.) larvae. In: Skjoldal HR, Hopkins C, Erikstad KE, Leinaas HP (eds) Ecology of fjords and coastal waters. Elsevier, Amsterdam, p 365-384

Kiflawi M. Genin A (1997) Prey flux manipulation and the feeding rates of reef-dwelling planktivorous fish. Ecology 78:1062-1077

Kiørboe T, MacKenzie BR (1995) Turbulence-enhanced prey encounter rates in larval fish: effects of spatial scale, larval behaviour and size. J Plankton Res 17:2319-2331

Kiorboe T, Munk P (1986) Feeding and growth of larval herring. Clupea harengus, in telation to density of copepod nauplii. Environ Biol Fish 17:133-139

Kiorboe I, Saiz E (1995) Planktivorous feeding in calm and turbulent environments with emphasis on copepods. Mar Ecol Prog Ser 122:35-145

Kiørboe T, Munk P, Støttrup JG (1985) First feeding by larval herring Clupea harengus. Dana 5:95-107

Kiørboe T, Munk P, Richardson K (1987) Respiration and growth of larval herring Clupea harengus: relation between specific dynamic action and growth efficiency. Mar Ecol Prog Ser 40:1-10

Kiorboe T, Munk P, Richardson K, Christensen V, Paulsen H (1988) Plankton dynamics and larval herring growth, drift and survival in a frontal area. Mar Ecol Prog Ser 44 $205-219$

Laurence GC (1.978) Comparative growth, respiration and delayed feeding abilities of larval cod (Gadus morhua) and haddock (Melanogrammus aeglefinus) as influenced by temperature during laboratory studies. Mar Biol 50:1-7

Leggett WC, Deblois E (1994) Recruitment in marine fishes: is it regulated by starvation and predation in the egg and larval stages? Neth J Sea Res 32:119-134

Letcher BH, Rice JA, Crowder LB, Rose KA (1996) Variability in survival of larval fish: disentangling components with a generalised individual-based model. Can J Fish Aquat Sci $53: 787-801$

Loehle C (1983) Evaluation of theories and calculation tools in ecology. Ecol Model 19:239-247

Mackenzie BR, Leggett WC (1993) Wind-based models for estimating the dissipation rates of turbulent energy in aquatic environments: empirical comparisons. Mar Ecol Prog Ser 94:207-216

MacKenzie BR, Leggett WC, Peters RH (1990) Estimating larval fish ingestion rates: can laboratory derived values be reliably extrapolated to the wild? Mar Ecol Prog Ser 67: $209-225$

MacKenzie BR, Miller TJ, Cyr S, Leggett WC (1994) Evidence for a dome-shaped relationship between turbulence and larval fish ingestion rate. Limnol Oceanogr 39 . $1790-1799$

MCNamara JM, Houston AI (1987) Starvation and predation as factors limiting population size. Ecology 68:1515-1519

Miller TJ, Crowder LB, Rice JA, Marschall. EA (1988) Larval size and recruitment mechanisms in. fishes: towards a conceptual framework. Can J Fish Aquat Sci 45:1657-1670

Miner JG, Stein RA (1993) Interactive influence of turbidity and light on larval bluegill (Lepomis macrochirus) foraging. Can J Fish Aquat Sci 50:781-788

Muelbert. JH, Lewis MR, Kelley DE (1994) The importance of small-scale turbulence in the feeding of herring larvae. J Plankton Res 16:927-944

Munk P (1992) Foraging behaviour and prey size spectra of larval herring Clupea harengus. Mar Ecol Prog Ser 80: $149-158$ 
Munk P, Kiorboe T (1985) Feeding behaviour and swimming activity of larval herring (Clupea harengus) in relation to density of copepod nauplii. Mar Ecol Prog Ser 24:15-21

Øiestad V (1985) Predation on fish larvae as a regulatory force, illustrated in mesocosm studies with large groups of larvae. Northw Atl Fish Org Sci Coun Stud 8:25-32

Packard A, Wainwright AW (1974) Brain growth of young herring and trout. In: Blaxter JHS (ed) The early life history of fish. Springer Verlag, Berlin, p 499-507

Pedersen BH, Ugelstad I, Hjelmeland K (1990) Effects of a transitory, low food supply in the early life of larval herring (Clupea harengus) on mortality, growth and digestive capacity. Mar Biol 107:61-66

Rose KA, Cowan JH Jr (1993) Individual-based model of young-of-the-year striped bass population dynamics. I. Model description and baseline simulations. Trans Am Fish Soc 122:415-438

Rosenthal H, Hempel G (1970) Experimental studies in feeding and food requirements of herring larvae (Clupea harengus). In: Steele JH (ed) Marine food chains. Oliver and Boyd, Edinburgh, p 344-364

Rosland R, Giske J (1994) A dynamic optimization model of the diel vertical distribution of a pelagic planktivorous fish. Prog Oceanogr 34:1-43

Rosland R, Giske J (1997) A dynamic model for the life history

Editorial responsibility: Otto Kinne (Editor),

Oldendort/Luhe, Germany of Maurolicus muelleri, a pelagic planktivorous fish. Fish Oceanogr 6:19-34

Rothschild BJ, Osborn TR (1988) Small-scale turbulence and plankton contact rates. J Plankton Res 10:465-474

Stephens DW, Krebs JR (1986) Foraging theory. Princeton University Press, Princeton, NJ, $247 \mathrm{p}$

Sundby S, Fossum P (1990) Feeding conditions of ArctoNorwegian cod larvae compared to the Rothschild-Osborn theory on small-scale turbulence and plankton contact rates. J Plankton Res 12:1153-1162

Sundby S, Ellertsen B, Fossum P (1994) Encounter rates between first feeding cod larvae and their prey during moderate to strong winds. ICES Mar Sci Symp 198:393-405

Suthers IM. Sundby S (1996) Role of the midnight sun: comparative growth of pelagic juvenile cod (Gadus morhua) from the Arcto-Norwegian and a Nova Scotian stock. ICES J Mar Sci 53:827-837

Walton WE, Hairston NG, Wetterer JK (1992) Growth-related constraints on the diet selection by sunfish. Ecology 73:429-437

Werner FE, Perry RI, Lough RG, Naimie CE (1996) Trophodynamic and advective influences on Georges Bank larval cod and haddock. Deep-Sea Res II 43:1793-1822

Werner RG, Blaxter JHS (1980) Growth and survival of larval herring (Clupea harengus) in relation to prey density. Can J Fish Aquat Sci 37:1063-1069

Submitted: December 3, 1998; Accepted: February 3, 1999

Proofs received from author(s): June 30, 1999 